\title{
Transport of L-Methionine in Rat Intestine and Kidney
}

\author{
Christos S. Bartsocas, ${ }^{[13]}$ Samuel O. Thier, and John D. Crawford \\ Children's Service and Renal Unit, Medical Service, Massachusetts General Hospital, and Departments of Pediatrics and Medicine, \\ Harvard Medical School, Boston, Massachusetts, USA
}

\section{Extract}

L-Methionine transport was studied in vitro in rat kidney cortex slices and intestinal segments.

In both tissues $\mathrm{L}-\left(\mathrm{C}^{14}\right)$ methionine at concentrations of $0.065 \mathrm{mmol}$ was accumulated against a chemical concentration gradient by processes which obeyed saturation kinetics. In both tissues anaerobic conditions (incubation in $95 \% \mathrm{~N}_{2}$ and $5 \% \mathrm{O}_{2}$ atmosphere $)$ inhibited methionine accumulation $(P<0.001$ and $P<0.025$, respectively). The processes were sodium dependent. Addition of $0.3 \mathrm{~m}$ sucrose produced significant $(P<0.001)$ inhibition of L-methionine accumulation in the kidney. L-Methionine transport was essentially $\mathrm{pH}$ independent. A series of amino acids, including representatives of the neutral, dibasic and imino acid groups at $2.4 \mathrm{~mm}$ concentrations, failed to inhibit methionine transport with the exception that valine proved a potent inhibitor of transport in the intestine $(P<0.01)$ and ethionine in the kidney $(P<0.025)$. Methionine inhibited glycine accumulation in the kidney $(P<0.025)$ and intestine $(P<0.001)$, but failed to affect lysine transport in either tissue.

\section{Speculation}

The data presented indicate that methionine uptake in the gut and the kidney has the characteristics of an active transport process which is unaffected by most other amino acids. These findings suggest that methionine is either transported by an independent mechanism and/or by a transport system which is shared with the other neutral amino acids but for which it has a much higher affinity.

\section{Introduction}

The variability in methionine excretion in Hartnup disease [9], coupled with the recognition of the isolated methionine malabsorption syndrome $[4,5]$, led to the study of L-methionine transport in vitro in rat kidney cortex slices and intestinal segments. In fact, in the latter syndrome, an association of a renal lesion with the existing intestinal one was demonstrated indirectly by intermittent methioninuria which became more marked after oral methionine administration [3, $10]$.

\section{Materials and Methods}

Male Sprague-Dawley rats, weighing 140-160 g, were fed ad libitum a Purina rat chow diet until the time of killing by stunning and decapitation. The kidneys were removed through an abdominal incision and bisected transversely. The capsule was stripped off, and 
thin cortical slices $(0.4 \mathrm{~mm})$ were made with a StadieRiggs microtome. The initial subcapsular slice from each hemikidney was discarded and three slices which contained cortical tissue only were obtained from each half.

After this step, the small intestine of the rats was removed beginning at a point $12 \mathrm{~cm}$ from the pylorus. A segment $4 \mathrm{~cm}$ in length distal to this point was mounted on a glass rod, everted, and cut into 12 jejunal rings.

Except where otherwise stated, the specimens of the intestinal mucosa and of the cortex were incubated aerobically ( $95 \%$ oxygen and $5 \%$ carbon dioxide) in Krebs-Ringer bicarbonate buffer containing L-methionine uniformly labeled with radioactive carbon $\left({ }^{14} \mathrm{C}\right)$ or any of the other amino acids tested at concentrations of $0.065 \mathrm{mmol}$ or as stated.

After incubation of kidney for $90 \mathrm{~min}$ or of intestine for $60 \mathrm{~min}$ at $37^{\circ}$ in a Dubnoff metabolic shaker, the specimens were rinsed in saline solution, blotted, and weighed. The free amino acid content of the tissues was equilibrated with $2 \mathrm{ml}$ distilled water by boiling. Two-tenths-milliliter samples of aqueous tissue extract and of the media were counted in a liquid scintillation spectrometer. Tissue accumulation of ${ }^{14} \mathrm{C}$-labeled amino acid was calculated as a distribution ratio, (counts per minute per milliliter of intracellular fluid)/(counts per minute per milliliter of medium),

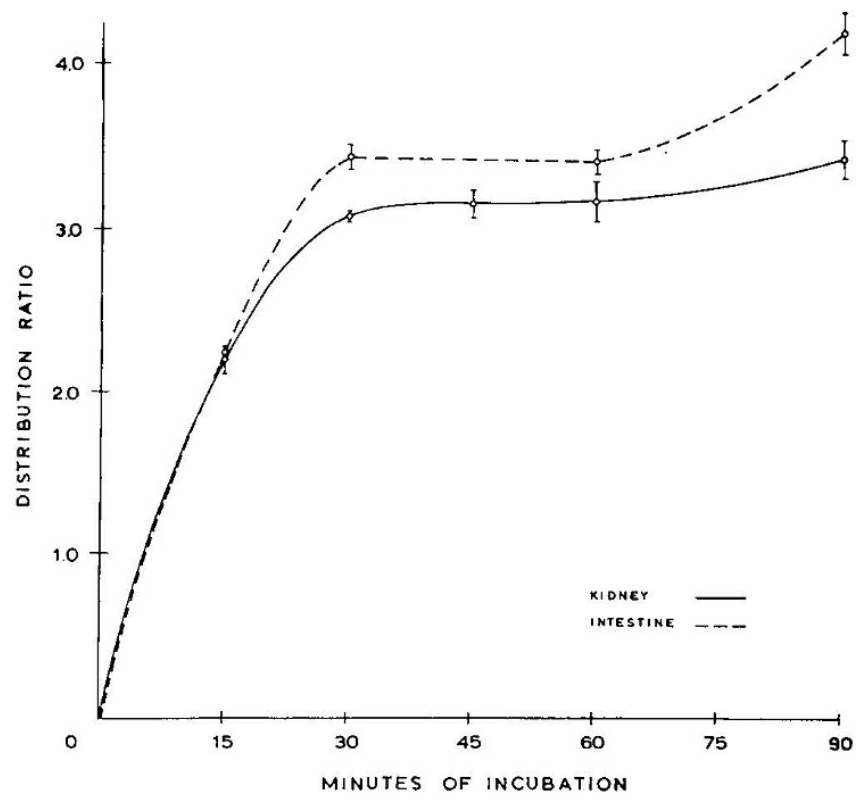

Fig. 1. Time course of $\mathrm{L}-\left({ }^{14} \mathrm{C}\right)$ methionine accumulation. Each point represents the mean of four to eight determinations $\pm \mathrm{SE}$. using inulin space and total tissue water as described previously $[6,7]$.

Chromatography of tissue extract performed at 60 min in the intestine and $90 \mathrm{~min}$ in the kidney revealed that $86 \%$ of the intracellular radioactivity was free $\mathrm{L}$ methionine in the former and $79 \%$ was free L-methionine in the latter. It should be clear that at the earlier time points at least that amount of methionine would have been unmetabolized. In fact, the use of these time points would allow an estimate of the greatest amount of metabolism to be achieved in our studies.

Experiments in both tissues were carried out to evaluate whether $\mathrm{L}-\left({ }^{14} \mathrm{C}\right)$ methionine was accumulated against a chemical concentration gradient, whether its transport had the characteristics of an active process, and whether it affected the active transport of other amino acids or, conversely, whether they influenced $\mathrm{L}$ methionine transport.

\section{Results and Discussion}

In a recent review, kidney cortex slices were noted to accumulate amino acids by processes which obeyed saturation kinetics, were energy dependent, sodium dependent, variably $\mathrm{pH}$ dependent, and which possessed some stereospecificity. The processes in the kidney cortex share many properties with transport processes in the intestinal mucosa and appear to be under similar genetic control [8]. This study evaluates the accumulation of methionine in rat kidney cortex slices and intestinal mucosa in the light of defined characteristics of amino acid transport in these tissues.

Data on the accumulation of L-methionine by kidney and intestine are presented in Figure 1. In both intestine and kidney tissue, the distribution ratio exceeded 1.0, which indicates concentration against a chemical gradient. The time course of L$\left({ }^{14} \mathrm{C}\right)$ methionine uptake by kidney cortex slices and jejunal rings is presented in Figure 1. The velocity of tissue accumulation of the amino acid was maximal during the first $30 \mathrm{~min}$ of incubation and then slowed to achieve a steady state. The time intervals of $90 \mathrm{~min}$ for the kidney and $60 \mathrm{~min}$ for the intestine were chosen for the experiments to coincide with time sequences published previously and were obviously points at steady state.

Saturable uptake and Michaelis-Menten analyses of the transport behavior of the two tissues are shown in Figure 2. The time period for these studies was $30 \mathrm{~min}$ for both kidney and intestine. This interval represents the end of the linear phase of uptake and therefore, 


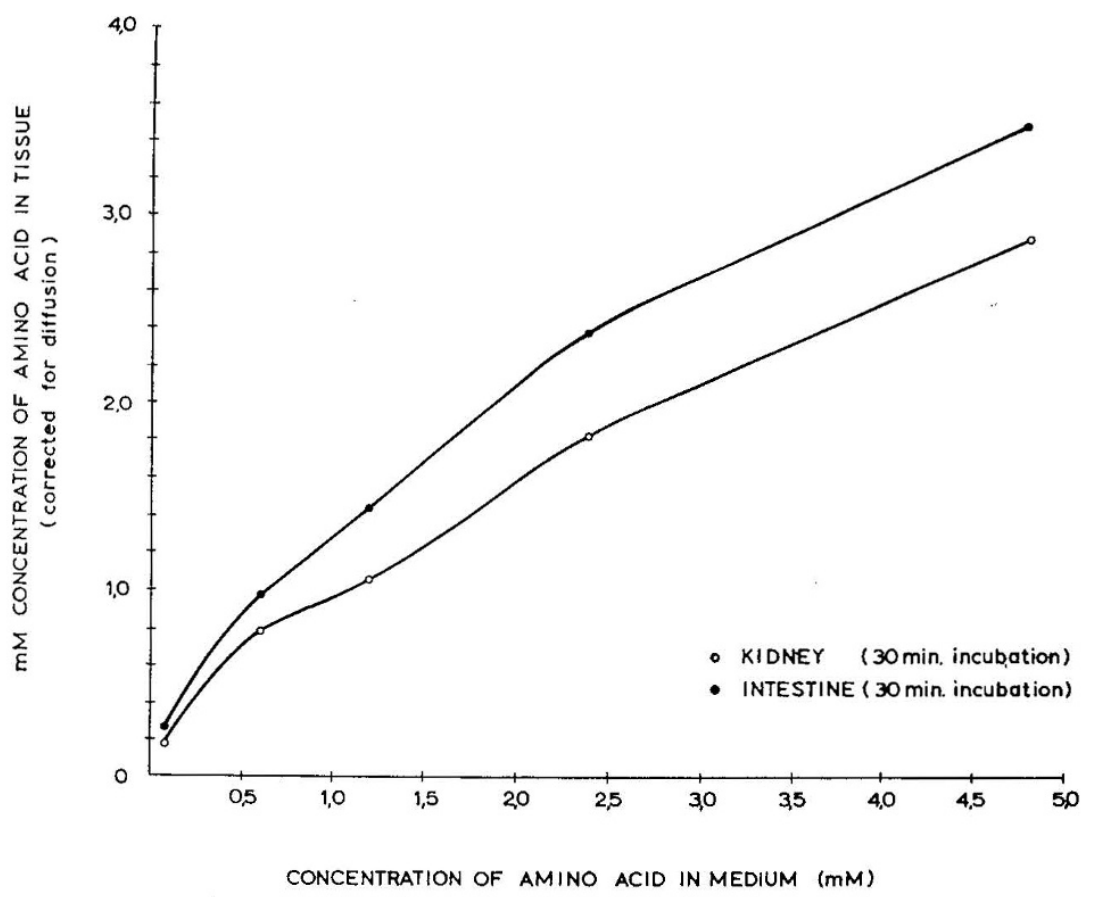

Fig. 2. Saturable uptake and Michaelis-Menten analyses of $\mathrm{L}-\left({ }^{14} \mathrm{C}\right)$ methionine transport by kidney and intestine. Values were corrected for diffusion by subtracting I from the distribution ratio and multiplying the remainder by the medium concentration [1].

Table I. $\mathrm{L}-\left({ }^{14} \mathrm{C}\right)$ Methionine accumulation under anaerobic conditions

\begin{tabular}{ccccccc}
\hline & \multicolumn{2}{c}{ Kidney $(90$-min incubation) } & & \multicolumn{2}{c}{ Intestine (60-min incubation) } \\
\cline { 2 - 3 } \cline { 5 - 6 } & Control & Anaerobic & & Control & Anaerobic \\
\hline Distribution ratio, $\pm \mathrm{SE}$ & $4.50 \pm 0.497$ & $1.50 \pm 0.283$ & & $2.68 \pm 0.268$ & $1.54 \pm 0.274$ \\
$P$ & 4 & 4 & & 4 & 4 \\
\hline
\end{tabular}

Table II. $\mathrm{L}-\left({ }^{14} \mathrm{C}\right)$ Methionine accumulation in sodium-free medium

\begin{tabular}{|c|c|c|c|c|}
\hline & \multicolumn{2}{|c|}{ Kidney (90-min incubation) } & \multicolumn{2}{|c|}{ Intestine (60-min incubation) } \\
\hline & Control & Tris & Control & Tris \\
\hline $\begin{array}{c}\text { Distribution ratio, } \pm \mathrm{SE} \\
n \\
P\end{array}$ & $\begin{array}{c}3.47 \pm 0.206 \\
9\end{array}$ & $\begin{array}{c}2.36 \pm 0.184 \\
9 \\
<0.001\end{array}$ & $\begin{array}{c}2.59 \pm 0.404 \\
6\end{array}$ & $\begin{array}{c}1.93 \pm 0.218 \\
6 \\
\text { N.S. }{ }^{1}\end{array}$ \\
\hline
\end{tabular}

${ }^{1}$ Not significant.

best approximates initial rates while allowing adequate quantitative uptake for accuracy. The transport may be a saturable process in that the rates of accumulation fall off at high medium concentrations. Actual saturation was not observed at the medium concentrations used.

The dependence of $\mathrm{L}-\left({ }^{14} \mathrm{C}\right)$ methionine transport on oxidative metabolism was tested in both tissues by incubating them in an atmosphere of $95 \% \mathrm{~N}_{2}$ and $5 \%$ $\mathrm{CO}_{2}$. The results shown in Table I indicate inhibition of $\mathrm{L}-\left({ }^{14} \mathrm{C}\right)$ methionine uptake by oxygen lack. This suggests that the uptake of L-methionine is dependent upon an oxygen-requiring transport process.

$\mathrm{L}-\left({ }^{14} \mathrm{C}\right)$ Methionine accumulation was dependent upon the presence of sodium. Incubation in sodiumfree Tris buffer resulted in an inhibition of the active transport of $\mathrm{L}-\left({ }^{14} \mathrm{C}\right)$ methionine in the kidney; however, the reduction is not seen in the gut (Table II). Table III shows that accumulation of $\left.\mathrm{L}^{-14} \mathrm{C}\right)$ methionine by kidney slices is inhibited by $0.3 \mathrm{~m}$ sucrose. 
Table IV demonstrates $\mathrm{L}-\left({ }^{14} \mathrm{C}\right)$ methionine accumulation by kidney cortex slices in relation to the $\mathrm{pH}$ of the medium. Transport was found to be relatively $\mathrm{pH}$ insensitive.

L- $\left({ }^{14} \mathrm{C}\right)$ Methionine accumulation by rat kidney was measured in the presence and absence of unlabeled Lproline, L-lysine, L-valine, L-ethionine, L-tryptophan, glycine, and L-leucine in $2.4 \mathrm{~mm}$ concentrations (Fig. 3). These amino acids, which represent neutral, dibasic, and imino acid groups, were tested as inhibitors of Lmethionine transport. The standard time used for incubations of kidney tissues was 90 min. Incubations of 30 min (during the linear uptake phase of amino acid) provided similar results. However, only L-ethionine was found to inhibit $\mathrm{L}-\left({ }^{14} \mathrm{C}\right)$ methionine transport. Ethionine, which is a methionine analog, has been found to be a potent inhibitor of methionine metabolism in a number of other systems.

The addition of either L-lysine or glycine at a concentration of $2.4 \mathrm{~mm}$ did not affect $\mathrm{L}-\left({ }^{14} \mathrm{C}\right)$ methionine accumulation by intestine (Table V). Hagihira et al. [2] observed competitive inhibition of methionine absorption by $\mathrm{L}$-valine, $\mathrm{x}$-leucine, and $\mathrm{L}$-isoleucine in intestinal absorption studies. It should be noted that we observed no inhibition of kidney cortex L$\left({ }^{14} \mathrm{C}\right)$ methionine transport by $\mathrm{L}$-leucine or $\mathrm{L}$-valine. However, the two tissues may differ in their ability to accumulate L-methionine, inasmuch as we, too, observed inhibition of $\mathrm{L}-\left({ }^{14} \mathrm{C}\right)$ methionine uptake by intestinal segments when $\mathrm{L}$-valine was added to the medium at a concentration of $2.4 \mathrm{~mm}$ (Table V).

Table III. L- $\left({ }^{14} \mathrm{C}\right)$ Methionine accumulation-inhibition by sucrose kidney (90-min incubation)

\begin{tabular}{ccc}
\hline & \multicolumn{2}{c}{ Kidney (90-min incubation) } \\
\cline { 2 - 3 } & Control & Sucrose \\
\hline $\begin{array}{ccc}\text { Distribution ratio, } \\
\text { mean } \pm \mathrm{SE}\end{array}$ & $5.22 \pm 0.715$ & $2.36 \pm 0.147$ \\
$n$ & 4 & 4 \\
$P$ & & $<0.001$ \\
\hline
\end{tabular}

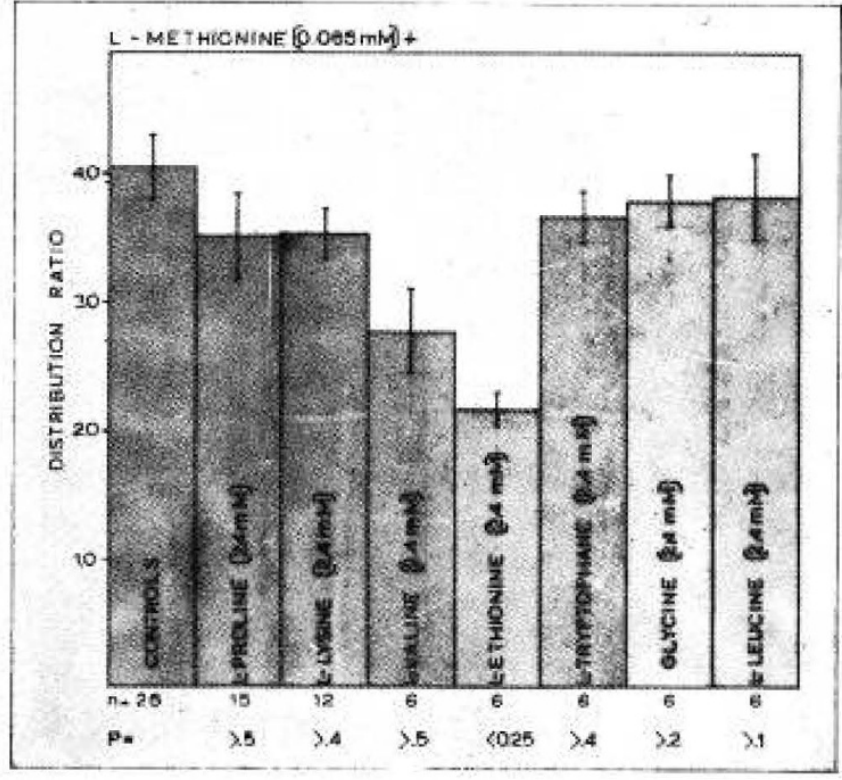

Fig. 3. Inhibition experiments of $\mathrm{L}_{-}\left({ }^{14} \mathrm{C}\right)$ methionine transport in the kidney (90-min incubations). Bars on each column represent SE values.

Table VI shows that no inhibition of $\mathrm{L}-\left({ }^{14} \mathrm{C}\right)$ lysine accumulation was observed when either kidney or intestine were incubated in medium containing L-methionine. On the other hand, uptake by both tissues of $\left({ }^{14} \mathrm{C}\right)$ glycine was significantly decreased when the medium included high concentrations of L-methionine. Again, neither L-lysine nor glycine inhibited L$\left({ }^{14} \mathrm{C}\right)$ methionine accumulation in either tissue. Thus, these and the experiments shown previously on labeled L-methionine uptake indicate that methionine inhibited glycine accumulation by the two tissues but evidence for glycine inhibition of L-methionine transport was lacking.

These results indicate that $\mathrm{L}-\left({ }^{\mathbf{1 4}} \mathrm{C}\right)$ methionine uptake by gut and kidney cortex has the characteristics of an active transport process. The system may be saturable, is oxygen dependent, and requires the presence of sodium in the medium. Addition of L-ethionine to the

Table IV. L- $\left({ }^{14} \mathrm{C}\right)$ Methionine accumulation, effect of $\mathrm{pH}$

\begin{tabular}{ccccccc}
\hline & \multicolumn{5}{c}{ Kidney (90-min incubation) } \\
\cline { 2 - 7 } & $\mathrm{pH} 5.75$ & $\mathrm{pH} 5.95$ & $\mathrm{pH} 6.40$ & $\mathrm{pH} 6.95$ & $\mathrm{pH} 7.45$ & $\mathrm{pH} 7.80$ \\
\hline $\begin{array}{c}\text { Distribution ratio, } \pm \mathrm{SE} \\
n\end{array}$ & $3.20 \pm 0.129$ & $3.10 \pm 0.22$ & $3.14 \pm 0.138$ & $3.02 \pm 0.190$ & $2.88 \pm 0.218$ & $3.06 \pm 0.212$ \\
$P$ & 4 & 4 & 4 & 4 & 4 & 4 \\
& N.S. & N.S. & N.S. & N.S. & N.S. & N.S.
\end{tabular}

${ }^{1}$ Not significant. 
Table V. L- $\left({ }^{14} \mathrm{C}\right)$ Methionine accumulation by rat intestine in presence of $\mathrm{L}$-valine, L-proline, L-lysine, and glycine (2.4 mM) with 60-min incubation

\begin{tabular}{|c|c|c|c|c|c|}
\hline & Control & $+\mathrm{x}-$ Valine & +L-Proline & +L-Lysine & +Glycine \\
\hline $\begin{array}{l}\text { Distribution ratio, mean } \\
\quad \pm \mathrm{sE}\end{array}$ & $2.61 \pm 0.385$ & $\mathrm{I} .85 \pm 0.335$ & $2.91 \pm 0.265$ & $2.61 \pm 0.398$ & $2.57 \pm 0.360$ \\
\hline $\begin{array}{l}n \\
P\end{array}$ & 10 & $\begin{array}{c}4 \\
<0.01\end{array}$ & $\begin{array}{c}4 \\
\text { N.S. }\end{array}$ & $\begin{array}{c}6 \\
\text { N.S. }\end{array}$ & $\begin{array}{l}10 \\
\text { N.S. }\end{array}$ \\
\hline
\end{tabular}

${ }^{1}$ Not significant.

Table VI. $\left({ }^{14} \mathrm{C}\right)$ Glycine and $\mathrm{L}-\left({ }^{14} \mathrm{C}\right)$ lysine accumulation in presence of $\mathrm{L}$-methionine $(2.4 \mathrm{~mm})$

\begin{tabular}{|c|c|c|c|c|}
\hline & $L-\left({ }^{14} \mathrm{C}\right)$ Lysine & $\begin{array}{l}\mathrm{L}-\left({ }^{(14} \mathrm{C}\right) \text { Lysine } \\
+\mathrm{L} \text {-methionine }\end{array}$ & $\left({ }^{14} \mathrm{C}\right)$ Glycine & $\begin{array}{l}\text { (14C) Glycine }+ \\
\text { L-Meethionine }\end{array}$ \\
\hline \multicolumn{5}{|l|}{ Kidney (90-min incubation) } \\
\hline $\begin{array}{c}\text { Distribution ratio, mean } \pm \mathrm{SE} \\
n\end{array}$ & $3.86 \pm 0.329$ & $\begin{array}{c}3.08 \pm 0.412 \\
10\end{array}$ & $\begin{array}{c}7.55 \pm 0.421 \\
11\end{array}$ & $5.10 \pm 0.228$ \\
\hline$P$ & & N.S.1 & & $<0.025$ \\
\hline \multicolumn{5}{|l|}{ Intestine (60-min incubation) } \\
\hline $\begin{array}{c}\text { Distribution ratio, mean } \pm \mathrm{SE} \\
n \\
P\end{array}$ & $\begin{array}{c}1.37 \pm 0.085 \\
17\end{array}$ & $\begin{array}{c}1.37 \pm 0.097 \\
15 \\
\text { N.S. }\end{array}$ & $\begin{array}{c}1.68 \pm 0.089 \\
14\end{array}$ & $\begin{array}{c}1.35 \pm 0.070 \\
14 \\
<0.001\end{array}$ \\
\hline
\end{tabular}

1 Not significant.

incubation medium diminished sharply $\mathrm{L}$ $\left({ }^{14} \mathrm{C}\right)$ methionine transport in the kidney cortex slice but no inhibition of ${ }^{\mathrm{L}-}\left({ }^{14} \mathrm{C}\right)$ methionine transport by representative members of the imino, dibasic, and branch chain amino acids was noted. L-Valine, which did not significantly inhibit L-methionine transport in the kidney, inhibited methionine uptake in the intestine.

Inhibition of $\left({ }^{14} \mathrm{C}\right)$ glycine transport by $\mathrm{x}$-methionine in both kidney and intestine was demonstrated. Glycine, a neutral amino acid, is thought to share a transport mechanism with the imino acids.

The findings suggest that L-methionine is transported by a system independent of the system(s) responsible for transport of the other neutral amino acids save glycine or that it has a much higher affinity for that system than any of the neutral amino acids tested.

\section{Summary}

L-Methionine transport was studied in vitro in rat kidney cortex slices and intestinal segments. In both tissues L-methionine was accumulated against a chemical concentration gradient by processes which obeyed saturation kinetics. A series of amino acids, including representatives of the neutral, dibasic, and imino acid groups, failed to inhibit methionine transport with the exception that valine proved to be a potent inhibitor of transport in the intestine and ethionine in the kidney. Methionine inhibited glycine accumulation in the kidney and intestine, but failed to affect lysine transport in either tissue.

Results indicate that methionine uptake in the gut and the kidney has the characteristics of an active transport process which is unaffected by most other amino acids. It is also suggested that methionine is either transported by an independent mechanism and/ or by a transport system which is shared with the other neutral amino acids, but for which it has a much higher affinity.

\section{References and Notes}

1. Akedo, H., and Christensen, H. N.: Nature of insulin action on amino acid uptake by the isolated diaphragm. J. Biol. Chem., 237: 118 (1962).

2. Hagihira, H., Ogata, M., Takedatsu, N., and Suda, M.: Intestinal absorption of amino acids. III. Interference between amino acids during intestinal absorption. J. Biochem., 47: 139 (1960).

3. Hooft, C.: Written communication, December 3, 1965.

4. Hooft, C., Trmmermans, J., Snoeck, J., Antener, I., Oyaert, W., AND van den HeNde, C.: Methionine malabsorption in a mentally defective child. Lancet, $i i$ : 20 (1964).

5. Hooft, C., Timmermans, J., Snoeck, J., Antener, I., Oyaert, W., AND VAN DEN HENDE, C.: Methionine malabsorption syndrome. Ann. Paediat., 205: 73 (1965).

6. Rosenberg, L. E., Blair, A., and Segal, S.: Transport of amino acids by slices of rat-kidney cortex. Biochim. Biophys. Acta, 54: 479 (1961). 
7. Rosenberg, L. E., Downing, S. J., and Segal, S.: Competitive inhibition of dibasic amino acid transport in rat kidney. $\mathrm{J}$. Biol. Chem., 237: 2265 (1962).

8. Segal, S., And Thier, S. O.: Renal handling of amino acids. In: J. Orloff and R. W. Berliner: Handbook of Physiology, Section 8: Renal Physiology (The American Physiological Society, Washington, D.C., 1973).

9. Shih, V. E., Bixby, E. M., Alpers, D. H., Bartsocas, C. S., AND THIER, S. O.: Studies of intestinal transport defect in Hartnup disease. Gastroenterology, 61: 445 (1971).
10. Thier, S. O., ANd Alpers, D. H.: Disorders of intestinal transport of amino acids. Amer. J. Dis. Child., 117: 13 (1969).

11. This research was supported by Grant no. HD-00033, National Institutes of Health.

12. The present address of Dr. S. O. Thier is: Department of Medicine, University of Pennsylvania School of Medicine, Philadelphia, Penn. 19104.

13. Requests for reprints should be addressed to: C. S. BArTsocas, M.D., 3 Kapsali St., Athens 138, Greece.

14. Accepted for publication February 11, 1974. 